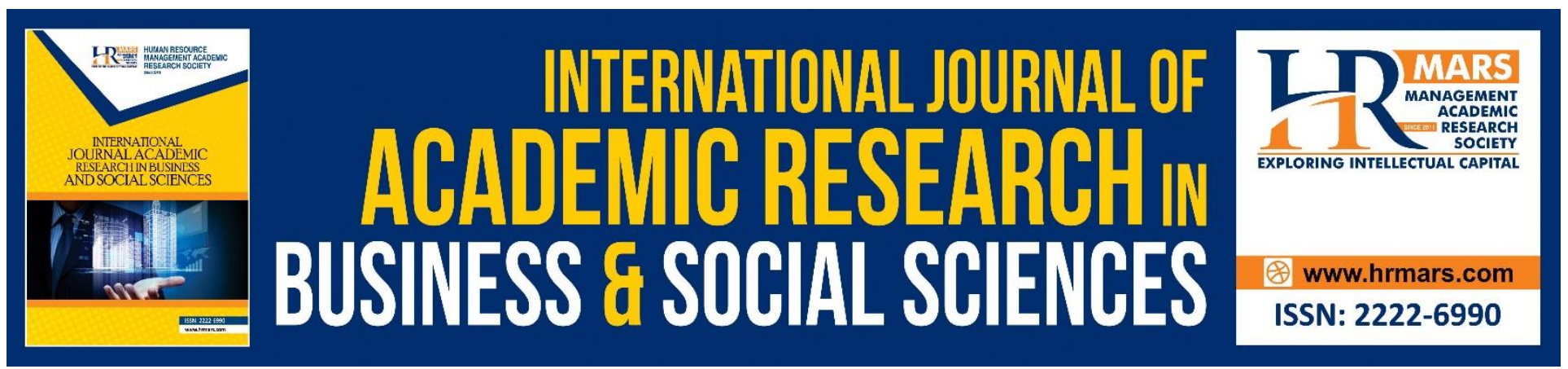

\title{
Perhentian Islands' Cost of Environment: Estimating the Loss of Revenue from Tourism Impact
}

Rosmini Ismail, Khalizul Khalid, Hartini Jaafar, Ramlee Ismail

To Link this Article: http://dx.doi.org/10.6007/IJARBSS/v10-i8/7639

DOI:10.6007/IJARBSS/v10-i8/7639

Received: 06 May 2020, Revised: 09 June 2020, Accepted: 14 July 2020

Published Online: 26 August 2020

In-Text Citation: (Ismail, Khalid, Jaafar, \& Ismail, 2020)

To Cite this Article: Ismail, R., Khalid, K., Jaafar, H., \& Ismail, R. (2020). Perhentian Islands' Cost of Environment: Estimating the Loss of Revenue from Tourism Impact. International Journal of Academic Research in Business and Social Sciences. 10(8), 826-842.

Copyright: @ 2020 The Author(s)

Published by Human Resource Management Academic Research Society (www.hrmars.com)

This article is published under the Creative Commons Attribution (CC BY 4.0) license. Anyone may reproduce, distribute, translate and create derivative works of this article (for both commercial and non-commercial purposes), subject to full attribution to the original publication and authors. The full terms of this license may be seen

at: http://creativecommons.org/licences/by/4.0/legalcode

Vol. 10, No. 8, 2020, Pg. 826 - 842

http://hrmars.com/index.php/pages/detail/IJARBSS

JOURNAL HOMEPAGE

Full Terms \& Conditions of access and use can be found at http://hrmars.com/index.php/pages/detail/publication-ethics 


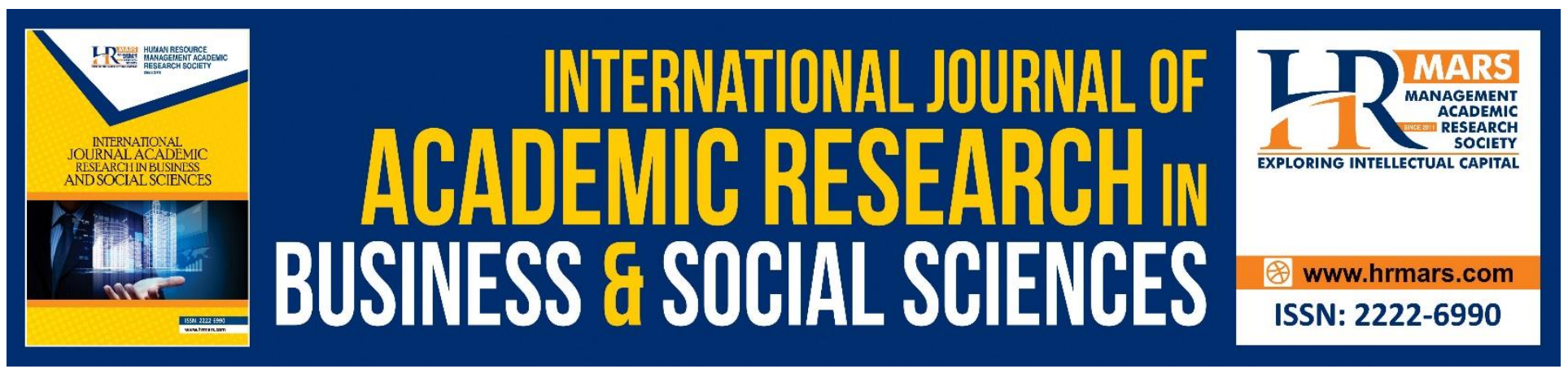

\title{
Perhentian Islands' Cost of Environment: Estimating the Loss of Revenue from Tourism Impact
}

\author{
Rosmini Ismail, Khalizul Khalid, Hartini Jaafar, Ramlee Ismail \\ Department of Accounting and Finance, Department of Business Management \& Entrepreneurship, \\ Department of Accounting and Finance, Department of Economics, Faculty of Management and \\ Economics, Universiti Pendidikan Sultan Idris, Tanjong Malim, Perak, Malaysia. \\ Email: Rosmini@fpe.upsi.edu.my
}

\begin{abstract}
Tourism activities typically caused disturbances to the functions provided by the environment. Regrettably, these environmental impacts are commonly ignored in the measurement of financial performance. Therefore, the focus of the study is to account for the environmental degradations such as overshoot and overcapacity of environmental resources and overuse of environmental asset. Consequently, the study estimates the Perhentian Islands' tourism revenue and use it as a proxy to estimate the loss of revenue due to the environmental impact caused. Therefore, the paper highlights on financial estimates of environmental degradations and environmental asset overuse. The quantification of these estimates were based on secondary resources. Concurrently, the paper briefly discussed the estimation of tourism revenue which derived from 923 visitors spending on Perhentian Island, analysed using two-steps Chi-Square Automatic Interaction Detection (CHAID). The costs of the environment were measured loosely based on ecological footprint and tourism carrying capacity concepts, and economic valuation techniques. The findings suggest that the cost of the environment comprised of RM5, 446, 563.00 overshoot, RM506, 576.00 overcapacity and between 1, 343, 041.00 to 3, 357, 602.00 for environmental asset overuse. Thus, overall tourism cost of environment for Perhentian Island was recorded between RM 7, 296, 180.00 to -RM 9, 310, 741.00.

Keyword: Perhentian Islands, Cost of Environment, Loss of Revenue, Environmental Degradation, Environmental Asset Overuse.
\end{abstract}

\section{Introduction}

Tourism is a key industry for many countries, especially in supporting employment, infrastructure development and as a significant contributor to the GDP. World Tourism Organization (UNWTO) (2013) reported that the United States of America, Spain, France and China were the top 4 earner for international tourism receipt in 2012 with USD126, USD55.9, USD53.7 and USD50 billion respectively. Subsequently, the year 2012 is significant for the global tourism sector when it recorded more than 1 billion of international tourists' arrivals worldwide, and Malaysia was among the top 10 world destinations with France leading the category (World Tourism Organization (UNWTO), 2013). It has 
INTERNATIONAL JOURNAL OF ACADEMIC RESEARCH IN BUSINESS AND SOCIAL SCIENCES Vol. 10, No. 8, 2020, E-ISSN: 2222-6990 @ 2020 HRMARS

led to a positive trend for the tourism industry in Malaysia concerning tourism receipt with reported RM 69.1 billion in 2015, RM 82.1 billion for 2016, 82.2 billion in 2017 and 84.1billion for 2018 (Tourism Malaysia, 2019).

Unfortunately, tourism also contributes to undesirable social, cultural and environmental consequences. Various works of literature have documented negative impacts of tourism activities, namely degradation of natural capital (Gil, Renfro, Figueroa-Zavala, Penié, \& Dunton, 2015; Xiaojiang, 2008) and pollution of the seas and coastlines (El Sherbiny, Sherif, \& Hassan, 2006; Wilson \& Verlis, 2017). These types of impact caused significant concerns, especially for island destinations, since they are ecologically fragile and have limited resources (Balzan, Potschin-Young, \& Haines-Young, 2018). Most island destinations such as the Maldives, Bora Bora, Palawan, Koh Phi Phi and Perhentian Islands were heavily depended on its nature to attract visitors. Tagged as 'Sun, Sea and Sand' destinations, these islands were exposed to a high influx of tourists throughout the year. Since the islands were ecologically sensitive, high intensity of tourism activities may raise some sustainability issues. Rhodes Island in Greece, for example, is experiencing environmental degradation in some of its saturated area of crowded beaches (Vandarakis et al., 2018).

Perhentian Islands, the unit of analysis of this study also face several environmental issues from tourism activities. One of them is waste management, where an increasing number of tourists to the island caused a considerable volume of solid waste. It is argued that the current practice by transporting the waste $21 \mathrm{~km}$ away to the mainland is considered as uneconomical (Saat, 2017; Saat, Saputra, Jamin, Muhamad, \& Muhamad, 2019). Apart from that, erosions caused by illegal resorts and chalet on the island were also documented (Ramli \& Idris, 2016). In terms of visitors perception on tourism activities on the island, some studies found several issues in regards to crowdedness, impacts on vegetation, water quality and wildlife (Nejati, Mohamed, \& Omar, 2015; Ramdas \& Mohamed, 2017; Rasoolimanesh, Jaafar, Marzuki, \& Abdullah, 2017).

The sustainability of a tourism destination is crucial since it affects not only the host community but the whole nation as well. However, any form of tourism activities will give impact to the environments, especially those that heavily depended on natural landscape as attractions. Therefore, the question is, to what extent do these activities are allowed to occur? From the viewpoint of weak sustainability, manufactured capital can be substituted for losses in natural capital (Bartelmus, 2009). Arguably, as long as benefit exceeds the cost, the damages (limiting to recoverable state) may be tolerated. However, to do this, benefits and costs must first be defined and quantified. The main focus of the study is to measure the cost of the environment from tourism activities of a well-known island destination in Malaysia called Perhentian Islands. Therefore, the study embarked on the following objectives:

1. To estimate tourism revenue based on segmented visitor spending

2. To estimate loss of revenue from overcapacity and overshoot of environmental resources

3. To estimate loss of revenue from overuse of environmental asset

\section{Literature Review}


INTERNATIONAL JOURNAL OF ACADEMIC RESEARCH IN BUSINESS AND SOCIAL SCIENCES Vol. 10, No. 8, 2020, E-ISSN: 2222-6990 @ 2020 HRMARS

Tourism often points to activities that relate to leisure, recreation and hospitality (Ghanem, 2017). At most times, these features (leisure, recreation and hospitality) represent tourism itself. World Tourism Organisation (UNWTO, 2012) defined tourism as a "movement of people, spatially and temporally, out of their communities for leisure and business purposes" where a tourist is defined as a visitor staying for more than 24 hours in a country visited for business or leisure purposes". In other words, tourism involves the movement of people to places for more than 24 hours out of their communities either for leisure or business purposes. However, these movements may cause impact to the environment, social and economic structure, as well as culture and lifestyles. On a positive note, the demand for tourists related facilities, spaces and needs for recreational and leisure has increased physical development at the tourism site (Dolnicar, Crouch, \& Long, 2008; Lim \& McAleer, 2005; Lundie et al., 2007). However, some activities may cause destructions to the environment, displacement of community and uncontrollable production of waste. It may lead to environmental, social and economic pressure (impact) that may degrade the beauty, joy and wealth of the tourism site. These negative impact threatened the livelihood of its host's residents.

Another tourism drawback is waste creation which is a common by-product for any human activity. A massive quantity of solid waste produced every year has raised concern in regards to earth capability in absorbing these unwanted residues (Mamouni Limnios, Ghadouani, Schilizzi, \& Mazzarol, 2009). Islands in Malaysia are said to have produced 400 metric tons of solid waste per day. It is estimated that 60 per cent was collected and disposed at landfills, $35 \%$ t are burned, and 5\% are dumped into the sea (Agamuthu \& Nagendran, 2011). While studies conducted by Zaki (2004) for Tioman Island and Rafee and Owee (2007) for Perhentian Island indicated that growing number of tourists especially during holidays would naturally show a more significant volume of waste disposal.

Consequently, Akadiri, Lasisi, Uzuner, and Akadiri (2020) concluded that tourism and the level of income/output are the major contributors to environmental pollution in several tourism island territories. Other than that, various tourism externalities were also documented in many island destinations such as loss of biodiversity in San Andres, Colombia (González-Gamboa, SantosMartínez, \& Herrera-Martínez, 2019), wastewater issues in some Croatia islands (Kasum, Primorac, \& Pilić, 2019) and degrading coastal water in Saint Martin Island in Bangladesh (Nafi \& Ahmed, 2017). Malaysia own island destinations such as Langkawi (Leman, Ramli, \& Khirotdin, 2016), Tioman (Chia, Ramachandran, Ho, \& Ng, 2018), Redang (Lachs et al., 2019), and Pangkor (Mohamad, Rahman, Bahauddin, \& Mohamed, 2015) were also subjected to these types of environmental impact.

As a result, various studies were conducted to evaluate and promote sustainable tourism practices. Sustainable tourism studies have been growing ever since the phrase 'sustainable development' was coined (Ruhanen, Weiler, Moyle, \& McLennan, 2015). Meanwhile, within the perspective of the environment, studies include measuring tourism impacts through assessments such as carrying capacity (Lobo et al., 2013; Papayannis, 2017; Salerno et al., 2013), ecological footprint (Patterson, Niccolucci, \& Marchettini, 2008; Rees, 2017) which sometimes distinguishing specific footprints such as carbon footprint (Dwyer, Forsyth, Spurr, \& Hoque, 2010; Kuo \& Chen, 2009; Luo, Becken, \& Zhong, 2018) and water footprint for tourism destinations (Cazcarro, Hoekstra, \& Sánchez Chóliz, 2014; Ewing et al., 2012). 
INTERNATIONAL JOURNAL OF ACADEMIC RESEARCH IN BUSINESS AND SOCIAL SCIENCES Vol. 10, No. 8, 2020, E-ISSN: 2222-6990 @ 2020 HRMARS

In Malaysia, ample of sustainable tourism studies focus on the green practice of the hospitality sector such as hotels (Deraman, Ismail, Arifin, Izzat, \& Mostafa, 2017; Yusof \& Jamaludin, 2018), restaurants (Chia, Lai, Lau, Liong, \& Samantha, 2018; Tan, Khan, \& Lau, 2018) and consumer satisfaction on green practice by tourism operators (Azam, Rashid, \& Zainol, 2017; Yusof, Awang, Jusoff, \& Ibrahim, 2017; Yusof, Ibrahim, \& Awang, 2018). Furthermore, carrying capacity assessment and economic valuation were also conducted to evaluate the prospect of sustainable tourism development (Mohamad \& Marzuki, 2018; Zhang \& Chung, 2015; Zhang, Chung, \& Qiu, 2016). These include determining conservation values of specific natural attractions such as marine turtles (Teh, Teh, \& Jolis, 2018) mangrove forest, (Ramli, Samdin, \& Ghani, 2017) wetland (Siew, Yacob, Radam, Adamu, \& Alias, 2015) and marine parks (Gaik \& Izarenah, 2016).

Additionally, within the sustainable tourism context, there were also notions of accounting for the environment and report them alongside economic indicators. In earlier proposals, Dwyer and Forsyth (1997) suggest that the concept of tourism yield to include environmental externalities. Recent works within this scope of studies showed positive progress where environmental impact especially carbon emissions were recognised, measured and inserted into the tourism satellite account ( $\mathrm{Li}, \mathrm{Li}, \mathrm{Tang}, \&$ Wang, 2019; Sun et al., 2019; Tang \& Ge, 2018). Following the path to account for the environment, this study utilised tourism impact assessment reports to estimate the cost of the environment for Perhentian Island in Malaysia.

\section{Methodology}

\section{The Site}

Perhentian Islands which comprised of two islands, namely Perhentian Kecil and Besar are located at the northeastern coast of Terengganu state (one of 14 states that form Malaysia). Visitors can access the islands through Kuala Besut Jetty which is the only entry point. Tourists were required to pay marine park conservation fee and fill in their particulars for documentation purposes. Boats to the Islands took for about forty-five minutes journey to either Perhentian Besar or Perhentian Kecil. Perhentian Islands are mostly famous for its snorkelling, sunbathing and scuba diving activities. Due to the islands beautiful beaches with turquoise water and splendour sighting of underwater sea creatures and corals,

\section{The Sampling}

Domestic and international tourists with distinct trip-related characteristics can be observed staying at the two different islands of Perhentian. For example, the majority of those with family prefer to stay on Perhentian Besar, while backpackers most likely crowded Perhentian Kecil. Therefore, to ensure the sampling represent the Perhentian Islands visitors' population, the study engaged in three layers of multistage sampling. The first layer is cluster sampling with cluster's represented by Perhentian Kecil and Perhentian Besar. Following that, zone sampling were administered by identifying three tourist spots for each island. Perhentian Kecil was represented by Teluk Aur, Pasir Panjang (Long Beach) and Kampung Pasir Hantu. While, Perhentian Besar main spots were Teluk Pauh, Tanjung Genting and Teluk Dalam. The final layer is the stratified sampling for types of tourists, namely international and domestic tourists. 
INTERNATIONAL JOURNAL OF ACADEMIC RESEARCH IN BUSINESS AND SOCIAL SCIENCES Vol. 10, No. 8, 2020, E-ISSN: 2222-6990 @ 2020 HRMARS

\section{Instrumentations \\ Survey}

Questionnaires were distributed to tourists according to zones following the three layers multistage sampling techniques. The questionnaire consists of four sections. The first section, $A$, comprises of demographic and socio-economic information. The next section, B concern with trip-related characteristics and nature of visiting. The third section consists of information on spending on the five types of expenditure (accommodation, food \& beverages, transportations, recreational and retail). The final part of the questionnaire is concerned with visitors' satisfaction and perceptions on tourism activities and facility provided on the Islands.

\section{Interviews}

Interviews were conducted to verify some observations made during data collection such as domestic and international tourists' trends according to a specific period (peak and off-peak), island location (Pulau Kecil and Besar), beaches and types of recreational activities. Interviews were also conducted with the Besut District Council officers to ascertain facilities provided on the island. Other than that, boatmen, host residents and tourists' operators were also interviewed.

\section{Secondary Resources}

Secondary data in the form of non-financial information including statistics of visitors' arrivals and quantification-related information for environmental degradation variables were also based on previous studies conducted on the island. The list of secondary resources utilised in the study were as follows:

i. Tourists arrival trend (Department of Marine Park Malaysia, 2016)

ii. Status of Coral Reefs in Malaysia, 2015 (Reef Check Malaysia, 2015).

iii. Study on the Repositioning Pulau Perhentian as a Premier Ecotourism Destination (Tourism Planning Research Group (TPRG), 2015)

iv. Planning Guidelines Physical Development of Islands and Marine Park (Department of Town and Country Planning Peninsular Malaysia, 2015)

v. Technical Ground Assessment Report for Perhentian Island (Mohamed, Salim, \& Siti Zulaiha, 2015)

vi. Total Economic Value of Marine Biodiversity Malaysia Marine Parks (Gaik \& Izarenah, 2016)

\section{The Analysis}

\section{Estimating Visitor Spending}

The estimation of tourism revenues were based on visitors spending through a segmented approach. In estimating tourism revenues, the study employed Stynes \& White (2006) 'Total spending for segmented analysis' to segment visitor spending. Visitor spending is segmented according to its predictor variable(s) namely, demographic (gender, age, income, marital status, country/state of origin and continent of origin-applicable to internationals only) and trip-related characteristics (length of stay, dependent on the trip-party size, location, motivation and companionship). In this study, two-step decision tree analyses were conducted utilising the Chi-squared Automatic Interaction Detection (CHAID). The first step involved running a dependent variable represented by continuous scale spending data against predictor variables consisting of demographic, trip-related 
INTERNATIONAL JOURNAL OF ACADEMIC RESEARCH IN BUSINESS AND SOCIAL SCIENCES Vol. 10, No. 8, 2020, E-ISSN: 2222-6990 @ 2020 HRMARS

and psychographic factors to generate a regression tree. The outputs from regression were then, run again in CHAID to produce a classification tree model. The study hypothesised that tourists' average spending on expenditure categories namely accommodation, food \& beverages, transportations, entertainment \& recreation and retail could be characterised or segmented according to the six demographic traits and five trip-related characteristics. CHAID algorithm is inserted into the segmented visitor spending estimation. The overall analysis for spending data using CHAID is demonstrated in Figure 1.

Figure 1: Visitor Spending Analysis Using CHAID

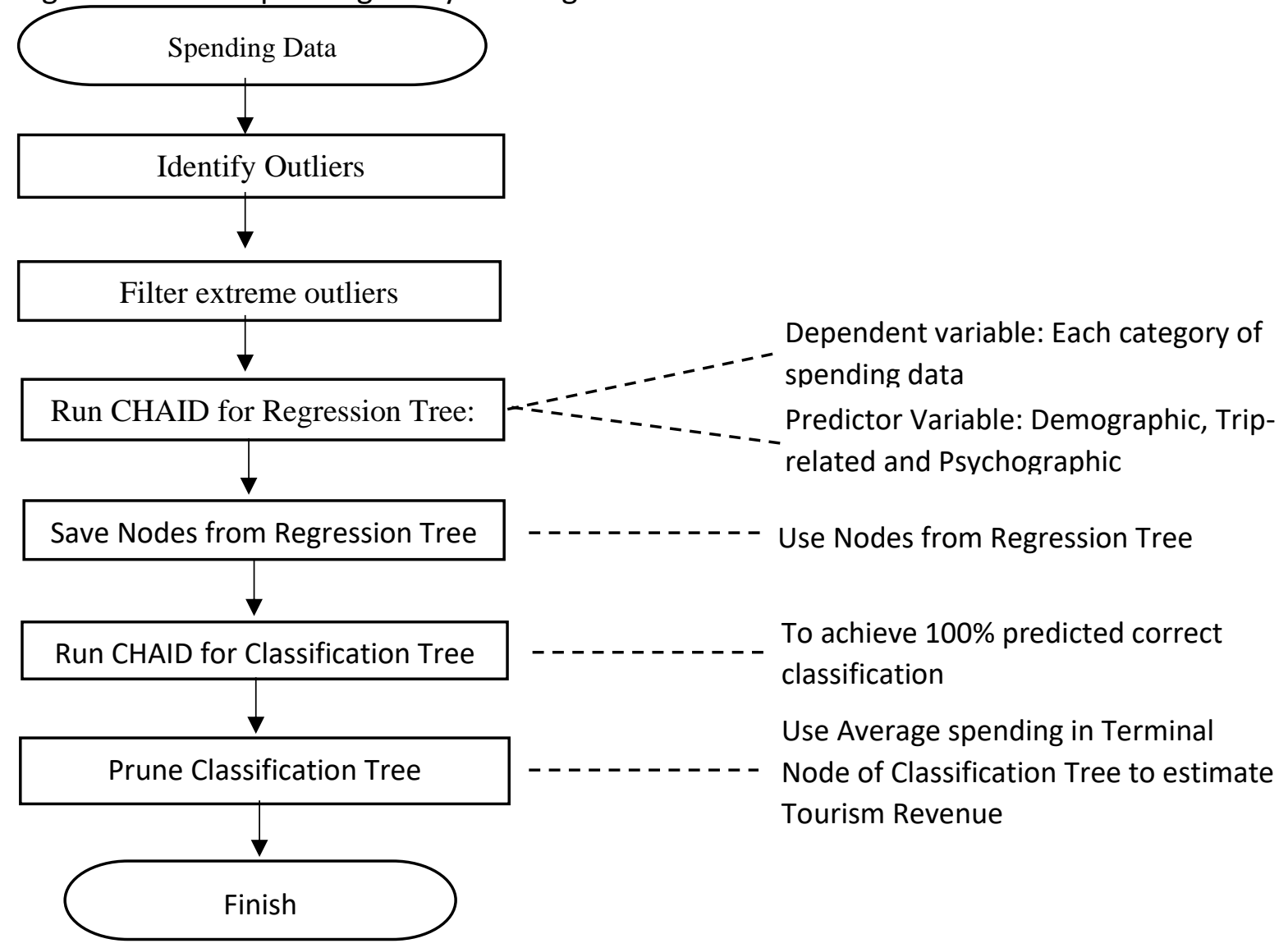

\section{Environmental Degradation}

Environmental degradations in this study represent overshoot and overcapacity of the island's resources to accommodate tourism activities. The study extracted information from three secondary resources to estimate the cost of the environment for environmental degradations, namely:

Study on the Repositioning Pulau Perhentian as a Premier Ecotourism Destination (Tourism Planning Research Group (TPRG), 2015)

This publication is a report by Tourism Malaysia that contains evaluation and recommendations for Perhentian Island to be repositioned as Eco-tourism destination. Recommendations were put forth by the study based upon the findings of current marine resources and terrestrial management, issues, and potential planning to promote Perhentian for eco-tourism activities. The study was conducted by the Tourism Planning Research Group (TPRG) with five objectives in focus. One of the objectives 
INTERNATIONAL JOURNAL OF ACADEMIC RESEARCH IN BUSINESS AND SOCIAL SCIENCES Vol. 10, No. 8, 2020, E-ISSN: 2222-6990 @ 2020 HRMARS

is to reduce social and environmental impact from tourism activities. Among findings in the study that were utilised by this thesis were carrying capacity, water quality and waste management assessment. Other than that, the thesis monetisation of overshoot was based on the study site audit for commercial accommodations which include location of resorts and chalet throughout the island, number of rooms available, average occupancy and density assessment.

\section{Planning Guidelines Physical Development of Islands and Marine Park (Department of Town and} Country Planning Peninsular Malaysia, 2015)

This publication is produced by the Department of Town and Country Planning that provides planning and development guidelines for islands and Marine Park in Malaysia. The guidelines contained definitions and categories of islands in Malaysia, policy and regulations and guidelines for planning and development according to the island categories.

Technical Ground Assessment Report for Perhentian Island (Mohamed, Salim, \& Zulaiha, 2015) The publication contained a report on ground observations and assessments on Perhentian Kecil and Besar in 2014. Observations and assessments were related to waste management, water quality, dive and snorkelling site, sewage assessment, beach assessment, crowdedness and distribution of facilities available throughout the island. The islands were divided into four zones, and measurement were based on a scale of 1 to 4 ; where ' 1 ' is very poor, and ' 4 ' is excellent. The report is used as an additional reference.

\section{Environmental Asset Overuse}

In this study, coral reefs have been identified as the main attraction of Perhentian Island. Therefore, the overuse of environmental asset points to Perhentian Islands coral reefs. The estimation of coral reefs overused is based upon information extracted from:

Status of Coral Reefs in Malaysia, 2015 (Reef Check Malaysia, 2015).

This report is published annually by Reef Check Malaysia that presented information relates to the health of coral reef $s$ off the East coast of Peninsular Malaysia and at sites around East Malaysia. The assessment and monitoring of coral reefs were conducted at over 150 sites which include Marine Parks such as Perhentian, Tioman, Redang Islands and many more. The annual report is made public and can be downloaded from RCM: www.reefcheck.org.my. For this study, only information concerning Perhentian Island coral reefs health classification were extracted to be used and adapted into the estimation of loss of revenue.

The estimation of loss of revenue for coral reef uses Reefs at Risk Threat Index as a proxy for future reef condition (Burke \& Maidens, 2004; Burke, Reytar, Spalding, \& Perry, 2011; Burke, Selig, \& Spalding, 2006). Although many economic valuation studies have focused on estimating the benefits of coral reef ecosystem services, some studies have also focused on changes in value-that is, what an economy stands to lose if a reef is degraded (Burke et al., 2011). This study adopted both types of economic valuation - benefit and loss of revenue for the coral reef. For loss of revenue, this study follows the Risk Threat Index. The Index outlined the decline in dive tourism can be associated with loss of revenue. It is between 1 to 10 per cent depending on the threat. Based on the Index, revenue can be retained $100 \%$ if the threat is low. However, if the threat is at a medium, the loss of revenue 
INTERNATIONAL JOURNAL OF ACADEMIC RESEARCH IN BUSINESS AND SOCIAL SCIENCES Vol. 10, No. 8, 2020, E-ISSN: 2222-6990 @ 2020 HRMARS

can be placed between 1 to 5 per cent. Meanwhile, at high-level threat, the loss of revenue is between 1 to 10 per cent. Since reef assessment by Reef Check Malaysia uses different classifications (Excellent, Good, Fair and Poor), some refinement to fit in the classification with the Index as illustrated in Table 1.

Table 1: Adapted Reef Check Classification into Reefs at Risk Threat Index

\begin{tabular}{ll}
\hline Reef Check Classification & Reefs at Risk Threat Index \\
\hline Excellent & Low threat \\
Good & Low threat \\
Fair & Medium threat \\
Poor & High threat \\
\hline
\end{tabular}

\section{Results and Discussions}

\section{Tourism Revenue}

Using visitor spending information gathered from respondents of the study, which consists of 402 domestic and 527 international, it is estimated that revenue derived from accommodations were $\mathrm{RM} 31,368,988.00$; food \& beverages RM23,374,245.81; transportation RM28,787,757.63; entertainment \& recreation RM35,087,164.81 and retail RM14,924, 146.60. Overall, this brings total revenue of RM 134, 304, 095.00, which include marine park fees of RM 76, 790.00 (RM5 per visitor).

\section{Cost of Environment}

The information for physical estimation of overshoot, overcapacity and overuse for Perhentian Island were extracted from secondary resources mentioned earlier. Consequently, it was stated that the maximum number of room that can be constructed for tourism activities were ten rooms for every acre of land. As illustrated in Table 2, the information in column A - E was provided by the secondary resources. Column $\mathrm{F}$ indicates the status of the area whether it is in comfort range or overshoot and overcapacity, while estimation of overshoot is shown in column $\mathrm{G}$ and. Each overshoot quantity is calculated is according to the area of which the building structure was constructed. It was found that a total number of 266 rooms were exceeding its land area limit with Long Beach with the most exceeding room with 132 rooms.

Meanwhile, estimation of overcapacity were presented in column $\mathrm{H}$, where the overcapacity was 532 visitors. The highest visitors' density were at Long Beach and followed by Teluk Keke. Long Beach is located at Perhentian Kecil, and Teluk Keke is at Perhentian Besar. However, Long Beach beds overcapacity is almost twice as Teluk Keke. It is due to the reason that there were more chalet and resort at Long Beach than any other beaches on Perhentian Island. Through observation, it is evidenced that the beach stretch at Long Beach was crowded with sunbathing tourists, especially in the afternoon. Meanwhile, at night, the beach was lively with performances and social gathering. 
INTERNATIONAL JOURNAL OF ACADEMIC RESEARCH IN BUSINESS AND SOCIAL SCIENCES Vol. 10, No. 8, 2020, E-ISSN: 2222-6990 @ 2020 HRMARS

Table 2: Overshoot and Overcapacity

\begin{tabular}{|c|c|c|c|c|c|c|c|}
\hline $\begin{array}{l}\text { Location } \\
\text { (A) }\end{array}$ & $\begin{array}{c}\text { Area } \\
\text { (B) }\end{array}$ & $\begin{array}{l}\text { Land } \\
\text { Area } \\
\text { (ac) } \\
\text { (C) }\end{array}$ & $\begin{array}{l}\text { Actual } \\
\text { number } \\
\text { of } \\
\text { rooms } \\
\text { (D) }\end{array}$ & $\begin{array}{c}\text { Optimal } \\
\text { number of } \\
\text { room } \\
\text { (10 rooms/ac) } \\
\text { (E) }\end{array}$ & $\begin{array}{l}\text { Overshoot (OS)/ } \\
\text { Overcapacity(OC) } \\
\text { (F) }\end{array}$ & $\begin{array}{l}\text { Estimated } \\
\text { Overshoot of } \\
\text { rooms } \\
\text { (G) }\end{array}$ & $\begin{array}{l}\text { Estimated } \\
\text { Overcapacity of } \\
\text { visitors ( } 2 \text { beds } \\
\text { per room) } \\
\text { (H) }\end{array}$ \\
\hline \multirow{4}{*}{$\begin{array}{l}\text { Perhentian } \\
\text { Kecil }\end{array}$} & $\begin{array}{l}\text { Long } \\
\text { Beach }\end{array}$ & 18.5 & 317 & 185 & Over & 132 & 264 \\
\hline & $\begin{array}{l}\text { Coral } \\
\text { Bay }\end{array}$ & 18.7 & 236 & 187 & Over & 49 & 98 \\
\hline & $\begin{array}{l}\text { Petani } \\
\text { Beach }\end{array}$ & 6 & 53 & 60 & Comfort range & - & \\
\hline & $\begin{array}{l}\text { Pasir } \\
\text { Hantu }\end{array}$ & 43 & 342 & 430 & Comfort range & - & \\
\hline \multirow{3}{*}{$\begin{array}{l}\text { Perhentian } \\
\text { Besar }\end{array}$} & $\begin{array}{l}\text { Teluk } \\
\text { Pauh }\end{array}$ & 31 & 295 & 310 & Comfort range & - & \\
\hline & $\begin{array}{l}\text { Teluk } \\
\text { Keke }\end{array}$ & 10 & 167 & 100 & Over & 67 & 134 \\
\hline & $\begin{array}{l}\text { Teluk } \\
\text { Dalam }\end{array}$ & 26 & 278 & 260 & Over & 18 & 36 \\
\hline \multicolumn{2}{|l|}{ Total } & 153.2 & 1688 & & Total OS/OC & 266 & 532 \\
\hline
\end{tabular}

The estimation of overshoot cost is based on revenue per acre derived from the total revenue of accommodation estimated earlier divide by total land area used to accommodate tourists. Revenue derived from accommodation were RM31, 368, 989.00 as calculated earlier. The area developed for commercial accommodations on the islands were approximately 153.2 acres. It brings to revenue per acre of RM204, 758.00. The quantification of overshoot were 26.6 ac (266/10 rooms per ac) which brings loss of revenue from overshoot of land usage as RM5,446,563.00.

Table 3: Cost of Overshoot

Land area used for tourists chalet, resort and hotels

Total revenue for accommodation

Revenue per acre

Land area required to accommodate overshoot (266 rooms/10 room) per

acre
$153.2 \mathrm{ac}$

RM31, 368, 989.00

\begin{tabular}{rr}
\hline Revenue per acre & RM 204, 758.00 \\
\hline $\begin{array}{r}\text { Land area required to accommodate } \\
\text { overshoot (266 rooms/10 room) per } \\
\text { acre }\end{array}$ & 26.6 ac \\
\hline Overshoot loss of revenue & RM 5, 446, 563.00 \\
\hline
\end{tabular}

It can be argued that overcapacity created the feeling of crowdedness that could lead to dissatisfaction. As a result, it may cause a loss of revenue. Therefore, the cost of overcapacity is calculated by multiplying the number of visitors exceeded the capacity with revenue per person. Revenue per person is calculated by summing up per-person spending on all expenditure types (accommodation, food \& beverages, transportations, recreational and retail). The cost of overcapacity is RM RM 506, 575.72, as demonstrated in Table 3. 
INTERNATIONAL JOURNAL OF ACADEMIC RESEARCH IN BUSINESS AND SOCIAL SCIENCES Vol. 10, No. 8, 2020, E-ISSN: 2222-6990 @ 2020 HRMARS

Table 4: Cost of overcapacity

Total average revenue per person on:

Accommodation: RM205.89

Food \& Beverages: RM153.42

Transportations: RM188.95

RM952.21

Recreational: RM255.31

Retail: RM148.64

Overcapacity quantity (visitors)

532

Overcapacity loss of revenue

RM 506, 575.72

As for the environmental asset overuse, extracting information from RCM report for 2015, it was stated that out of 10 coral reef sites surveyed in Perhentian Island, 10\% were in excellent condition, $40 \%$ were in good condition, and $50 \%$ were in fair condition. No reefs were reported to be in poor condition. Therefore, by using the Adapted Reef Check Classification into Reefs at Risk Threat Index, the excellent and good condition reefs can be classified as a low threat, and the fair condition is considered a medium threat. Therefore, the loss of income due to the deterioration of coral reef is estimated to be between RM1, 343, $040.94-\mathrm{RM} 3,357,602.37$. The estimation is illustrated in Table 4.

Table 5: Environmental Asset Lost of Revenue

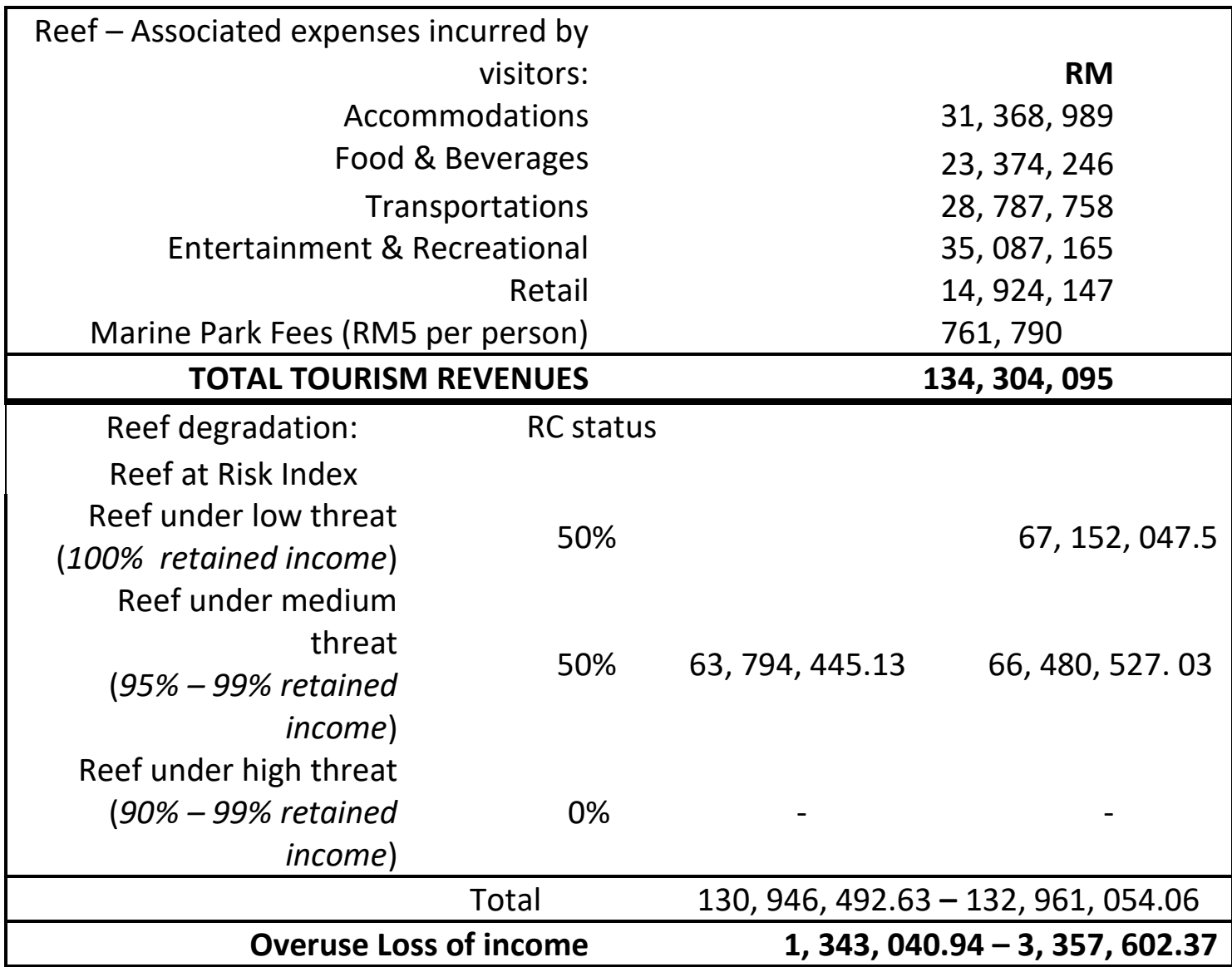


INTERNATIONAL JOURNAL OF ACADEMIC RESEARCH IN BUSINESS AND SOCIAL SCIENCES Vol. 10, No. 8, 2020, E-ISSN: 2222-6990 @ 2020 HRMARS

\section{Conclusions}

The objective of the study is to estimates the cost of the environment caused by tourism activities such as overshoot and overcapacity of environmental resources and overuse of environmental asset. The study first estimate Perhentian Island's tourism revenue and use it as a proxy to estimate the loss of revenue due to the environmental impact caused. The results for cost of the environment indicate that Perhentian Island may have overshoot, overcapacity and overuse its environments for tourism activities. The biggest over-degradation came from overshoot of land usage for commercially use buildings, especially for rental accommodation purposes has exceeded the maximum footprint per acre. The value of overshoot is estimated at RM5, 446, 563.00 (USD1, 361, 641.00).

Meanwhile, overcapacity in this study indirectly measures over-crowdedness where it evaluates visitors inhabiting a space. The study found that, during peak times, the maximum number of visitors occupying particular space may have been exceeded. It can be argued that the feeling of crowdedness could lead dissatisfaction and thus, loss of revenue. This value is estimated at RM506, 576.00 (USD126, 644.00) and representing the total exceeded number of visitors revenue per person. Finally, the overuse of environmental asset is estimated between RM1, 343, $041.00-3,357,602.00$ (USD335, 760.00 - USD839401.00). Environmental asset in this study is limited only to coral reefs. Indirectly, this cost measures coral reefs decline in value due to damages and loss of income. Therefore, the cost of the environment was recorded between RM 7, 296, 180.00 (USD1, 824, 045.00) (lower limit) and -RM 9, 310, 741.00 (USD2, 327, 685.00) (upper limit).

Theoretical and Contextual Implication

Overall, the study's empirical results and frameworks which were developed specifically for a tourism site contribute to tourism literatures especially within the context of island studies. These may accommodate gaps in literatures concerning island tourism destinations. The study also contributes methodologically in regards to the estimation of tourism revenue based on segmented visitor spending, measurements of environmental degradations in term of quantification approaches and techniques to translate physical units of degradations into financial value. Since there are limited studies that concern with measuring degradation through loss of revenue, this study offers different viewpoint in measuring impact on the natural environment. Finally, the framework of the study which incorporates various concepts and techniques from several field of studies; ultimately proposing a holistic view to account for the environment and thus, significantly contributes to the body of knowledge. Therefore, the study recommends that similar research and framework to be conducted and applied to other tourism islands as a monitoring tool to ensure that the islands' capacity is not exceeded.

\section{Acknowledgement}

This research has been carried out under Fundamental Research Grants Scheme (FRGS/1/2012/SS05/UPSI/03/2) provided by the Ministry of Education of Malaysia. The authors would like to extend their gratitude to Universiti Pendidikan Sultan Idris (UPSI) that helped manage the grants.

\section{References}

Agamuthu, P., \& Nagendran, P. (2011). Waste management challenges in sustainable development of islands. Retrieved from http://www.iswa.org website: 
INTERNATIONAL JOURNAL OF ACADEMIC RESEARCH IN BUSINESS AND SOCIAL SCIENCES

Vol. 10, No. 8, 2020, E-ISSN: 2222-6990 @ 2020 HRMARS

http://www.iswa.org/uploads/tx_iswaknowledgebase/Pariatamby.pdf

Akadiri, S. S., Lasisi, T. T., Uzuner, G., \& Akadiri, A. C. (2020). Examining the causal impacts of tourism, globalisation, economic growth and carbon emissions in tourism island territories: bootstrap panel Granger causality analysis. Current Issues in Tourism, 23(4), 470-484.

Azam, N., Rashid, B., \& Zainol, N. A. (2017). Conceptualising the Influence of Environmental Knowledge on Perceived Visit Value to Green Resort in Malaysia. J. Tour, 2, 1-17.

Balzan, M. V., Potschin-Young, M., \& Haines-Young, R. (2018). Island ecosystem services: insights from a literature review on case-study island ecosystem services and future prospects. International Journal of Biodiversity Science, Ecosystem Services \& Management, 14(1), 7190.

Bartelmus, P. (2009). The cost of natural capital consumption: Accounting for a sustainable world economy. Ecological Economics, 68(6), 1850-1857.

Burke, L., \& Maidens, J. (2004). Economic Valuation Methodology. World Resources Institute.

Burke, L., Reytar, K., Spalding, M., \& Perry, A. (Eds.). (2011). Reefs at risk revisited. Washington, DC: World Resources Institute. https://www.wri.org/publication/reefs-risk-revisited.

Burke, L., Selig, E., \& Spalding, M. (Eds.). (2006). Reefs at risk in Southeast Asia. USA: World Resources Institute (WRI) in collaboration with United Nations Environment Programme-World Conservation Monitoring Centre, World Fish Center and International Coral Reef Action Network. https://www.wri.org/publication/reefs-risk-southeast-asia.

Cazcarro, I., Hoekstra, A. Y., \& Sánchez Chóliz, J. (2014). The water footprint of tourism in Spain. Tourism Management, 40(0), 90-101. doi: http://dx.doi.org/10.1016/j.tourman.2013.05.010

Chia, K.-W., Ramachandran, S., Ho, J.-A., \& Ng, S. S.-I. (2018). Conflicts To Consensus: Stakeholder Perspectives Of Tioman Island Tourism Sustainability. International Journal of Business \& Society, 19.

Department of Marine Park Malaysia. (2016). Kompendium Data dan Maklumat Asas 2015-2016. Putrajaya: Department of Marine Park Malaysia, Ministry of Natural Resources and Environment Retrieved from http://www.dmpm. nre.gov.my/v1/eperpustakaan/kompendium-data-dan-maklumat-asas/.

Department of Marine Park Malaysia. (2018). Tourists Arrival Trend to Perhentian Island 2014 - 2016. Department of Marine Park Malaysia.

Department of Town and Country Planning Peninsular Malaysia. (2015). Garis Panduan Perancangan: Pembangunan Fizikal Pulau-pulau dan Taman laut. Malaysia: Jabatan Perancangan Bandar dan Desa Semenanjung Malaysia, Kementerian Perumahan dan Kerajaan Tempatan. http://www.planmalaysia.gov.my/index.php/garis-panduan-perancangan/2091-13-gp007-a2-gpp-pembangunan-fizikal-pulau-pulau-dan-taman-laut/file

Deraman, F., Ismail, N., Arifin, M., Izzat, A., \& Mostafa, M. I. A. (2017). Green practices in hotel industry: Factors influencing the implementation. Journal of Tourism, Hospitality \& Culinary Arts, 9(2), 1-12.

Dolnicar, S., Crouch, G. I., \& Long, P. (2008). Environment-friendly Tourists: What Do We Really Know About Them? Journal of Sustainable Tourism, 16(2), 197-210.

Dwyer, L., \& Forsyth, P. (1997). Measuring the benefits and yield from foreign tourism. International Journal of Social Economics, 24(1/2/3), 223-236.

Dwyer, L., Forsyth, P., Spurr, R., \& Hoque, S. (2010). Estimating the carbon footprint of Australian tourism. Journal of Sustainable Tourism, 18(3), 355-376. 
INTERNATIONAL JOURNAL OF ACADEMIC RESEARCH IN BUSINESS AND SOCIAL SCIENCES

Vol. 10, No. 8, 2020, E-ISSN: 2222-6990 @ 2020 HRMARS

El Sherbiny, A. H., Sherif, A. H., \& Hassan, A. N. (2006). Model for Environmental Risk Assessment of Tourism Project Construction on the Egyptian Red Sea Coast. Journal of Environmental Engineering, 132(10), 1272-1281.

Ewing, B. R., Hawkins, T. R., Wiedmann, T. O., Galli, A., Ertug Ercin, A., Weinzettel, J., \& Steen-Olsen, K. (2012). Integrating ecological and water footprint accounting in a multi-regional inputoutput framework. Ecological Indicators, 23(0), 1-8. DOI:

http://dx.doi.org/10.1016/j.ecolind.2012.02.025

Gaik, L. A., \& Izarenah, M. R. (Eds.). (2016). Total Economic Value of Marine Biodiversity Malaysia Marine Parks. Putrajaya: Department of Marine Park Malaysia, Ministry of Natural resources and Environment.

Ghanem, J. (2017). Conceptualising "The Tourist": A critical review of UNWTO definition. http://hdl.handle.net/10256/14825

Gil, M. A., Renfro, B., Figueroa-Zavala, B., Penié, I., \& Dunton, K. H. (2015). Rapid tourism growth and declining coral reefs in Akumal, Mexico. Marine biology, 162(11), 2225-2233.

González-Gamboa, I., Santos-Martínez, A., \& Herrera-Martínez, Y. (2019). Potential response of coral reef'S functional structure and snapper abundance to environmental degradation in san andres island, colombia. Acta Biológica Colombiana, 24(1), 86-96.

Kasum, J., Primorac, Z., \& Pilic, M. (2019). The Influence of Island Infrastructure on Security, Sustainability and Development of Nautical Tourism. In Katica Jureevie, Ljiljana Kaliterna Lipovean, Ozana Ramljak (Eds.) Reflections on The Mediterranean: Mediterranean Issues, Book 2. Pp. 305-316. Institute of Social Sciences Ivo Pilar. https://bib.irb.hr/datoteka/1009510.Zbornik_za_web_2018.pdf.

Kuo, N.-W., \& Chen, P.-H. (2009). Quantifying energy use, carbon dioxide emission, and other environmental loads from island tourism based on a life cycle assessment approach. Journal of Cleaner Production, 17(15), 1324-1330. DOI: http://dx.doi.org/10.1016/j.jclepro.2009.04.012.

Lachs, L., Johari, N. A. M., Le, D. Q., Safuan, C. D. M., Duprey, N. N., Tanaka, K., . . Baker, D. M. (2019). Effects of tourism-derived sewage on coral reefs: Isotopic assessments identify effective bioindicators. Marine Pollution Bulletin, 148, 85-96.

Leman, N., Ramli, M. F., \& Khirotdin, R. P. K. (2016). GIS-based integrated evaluation of environmentally sensitive areas (ESAs) for land use planning in Langkawi, Malaysia. Ecological Indicators, 61, 293-308.

Li, L., Li, J., Tang, L., \& Wang, S. (2019). Balancing Tourism's Economic Benefit and CO2 Emissions: An Insight from Input-Output and Tourism Satellite Account Analysis. Sustainability, 11(4), 1052.

Lim, C., \& McAleer, M. (2005). Ecologically sustainable tourism management. Environmental Modelling \&amp; Software, 20(11), 1431-1438. DOI: 10.1016/j.envsoft.2004.09.023

Lobo, H. A. S., Trajano, E., Marinho, M. D. A., Bichuette, M. E., Scaleante, J. A. B., Scaleante, O. A. F., . . . Laterza, F. V. (2013). Projection of tourist scenarios onto fragility maps: Framework for determination of provisional tourist carrying capacity in a Brazilian show cave. Tourism Management, 35(0), 234-243. DOI: http://dx.doi.org/10.1016/j.tourman.2012.07.008.

Lundie, S., Dwyer, L., \& Forsyth, P. (2007). Environmental-Economic Measures of Tourism Yield. Journal of Sustainable Tourism, 15(5), 503-519. DOI: 10.2167/jost713.0

Luo, F., Becken, S., \& Zhong, Y. (2018). Changing travel patterns in China and 'carbon footprint' implications for a domestic tourist destination. Tourism Management, 65, 1-13. 
INTERNATIONAL JOURNAL OF ACADEMIC RESEARCH IN BUSINESS AND SOCIAL SCIENCES

Vol. 10, No. 8, 2020, E-ISSN: 2222-6990 @ 2020 HRMARS

Limnios, M. E. A., Ghadouani, A., Schilizzi, S. G. M., \& Mazzarol, T. (2009). Giving the consumer the choice: A methodology for Product Ecological Footprint calculation. Ecological Economics, 68(10), 2525-2534.

Mohamad, D., \& Marzuki, A. (2018). Carrying Capacity of Tourism Development in Cameron Highlands, Malaysia. Planning Malaysia Journal, 16(8).

Mohamad, D., Rahman, S., Bahauddin, A., \& Mohamed, B. (2015). Physical environmental impacts of island tourism development: A case study of Pangkor Island. Geografia. Malaysian Journal of Society and Space, 11(11), 120-128.

Mohamed, B., Salim, N., \& Zulaiha, S. Z. A. (Eds.). (2015). Technical Ground Assessment Report for Perhentian Island. Penang: Sustainable Tourism Research Cluster (STRC), Universiti Sains Malaysia.

Zaki, M. O. (2004). Kajian pengurusan sisa pepejal pulau peranginan di Malaysia: Pulau Tioman. (ljazah Sarjana Muda Kejuruteraan Awam) [Unpublished degree dissertation], Universiti Teknologi Malaysia

Nafi, S. M., \& Ahmed, T. (2017). Sustainable tourism in Saint Martin Island: An observation on young tourist perception and awareness level. IOSR Journal of Humanities and Social Science (IOSRJHSS), 22(10), 73-80.

Nejati, M., Mohamed, B., \& Omar, S. I. (2015). The Influence of Perceived Environmental Impacts of Tourism on the Perceived Importance of Sustainable Tourism. E-review of Tourism Research, 12.

Papayannis, T. (2017). Tourism carrying capacity in areas of ecological importance The Challenge of Tourism Carrying Capacity Assessment (pp. 167-178): Routledge.

Patterson, T. M., Niccolucci, V., \& Marchettini, N. (2008). Adaptive environmental management of tourism in the Province of Siena, Italy using the ecological footprint. Journal of Environmental Management, 86(2), 407-418. DOI: http://dx.doi.org/10.1016/j.jenvman.2006.04.017.

Rafee, M., \& Owee, B. H. (2007). Sustainable solid waste management for island resorts: potential for Perhentian Island, Terengganu. Paper presented at the 1st International Conference on Built Environment in Developing Countries, Pulau Pinang.

Ramdas, M., \& Mohamed, B. (2017). Perceptions of Visitors and Residents on Impact of Tourism Activities towards Quality of Water in Redang and Perhentian Islands, Malaysia. Asian Journal of Technical Vocational Education and Training, 2(March), 1 - 7.

Ramli, F., Samdin, Z., \& Ghani, A. (2017). Willingness to pay for conservation fee using contingent valuation method: The case of Matang Mangrove Forest Reserve, Perak, Malaysia. Malaysian Forester, 80(1), 99-110.

Ramli, M. F., \& Idris, H. (2016). Pembangunan Mampan Pelancongan Maritim Di Pulau Perhentian, Terengganu (Sustainable Tourism Development At Perhentian Island, Terengganu). JatiJournal Of Southeast Asian Studies, 21, 108-124.

Rasoolimanesh, S. M., Jaafar, M., Marzuki, A., \& Abdullah, S. (2017). Tourist's perceptions of crowding at recreational sites: the case of the Perhentian Islands. Anatolia, 28(1), 41-51.

Reef Check Malaysia. (2015). Status of Coral Reefs in Malaysia, 2015. Retrieved from Reef Check Malaysia website: http://www.reefcheck.org.my/

Rees, W. E. (2017). Ecological Footprints and Appropriated Carrying Capacity: What Urban Economics Leaves Out. Urbanisation, 2(1), 66-77. DOI: 10.1177/2455747117699722 
INTERNATIONAL JOURNAL OF ACADEMIC RESEARCH IN BUSINESS AND SOCIAL SCIENCES Vol. 10, No. 8, 2020, E-ISSN: 2222-6990 @ 2020 HRMARS

Ruhanen, L., Weiler, B., Moyle, B. D., \& McLennan, C.-I. J. (2015). Trends and patterns in sustainable tourism research: a 25-year bibliometric analysis. Journal of Sustainable Tourism, 23(4), 517535.

Saat, S. A. (2017). The Needs of Sustainability Solid Waste Management in Perhentian Island, Terengganu. Paper presented at The European Conference on Sustainability, Energy \& the Environment 2017, July 7 - July 9, 2017, The Jurys Inn Brighton Waterfront, Brighton, United Kingdom.

Saat, S. A., Saputra, J., Jamin, R. M., Muhamad, R., \& Muhamad, R. (2019). A Study of Supply Chain Management for Sustainable Solid Waste Plan in Perhentian Island, Terengganu. Int. J Sup. Chain. Mgt Vol, 8(5), 1022.

Salerno, F., Viviano, G., Manfredi, E. C., Caroli, P., Thakuri, S., \& Tartari, G. (2013). Multiple Carrying Capacities from a management-oriented perspective to operationalise sustainable tourism in protected areas. Journal of Environmental Management, 128(0), 116-125. DOI: http://dx.doi.org/10.1016/j.jenvman.2013.04.043

Siew, M. K., Yacob, M. R., Radam, A., Adamu, A., \& Alias, E. F. (2015). Estimating willingness to pay for wetland conservation: a contingent valuation study of Paya Indah Wetland, Selangor Malaysia. Procedia Environmental Sciences, 30, 268-272.

Stynes, D. J., \& White, E. M. (2006). Reflections on measuring recreation and travel spending. Journal of Travel Research, 45(1), 8-16.

Sun, Y.-Y., Lenzen, M., \& Liu, B.-J. (2019). The national tourism carbon emission inventory: its importance, applications and allocation frameworks. Journal of Sustainable Tourism, 1-20.

Tan, B. C., Khan, N., \& Lau, T. C. (2018). Investigating the determinants of green restaurant patronage intention. Social Responsibility Journal, 14(3), 469-484.

Tang, M., \& Ge, S. (2018). Accounting for carbon emissions associated with tourism-related consumption. Tourism Economics, 24(5), 510-525.

Teh, L. S., Teh, L. C., \& Jolis, G. (2018). An economic approach to marine megafauna conservation in the coral triangle: Marine turtles in Sabah, Malaysia. Marine Policy, 89, 1-10.

Tourism Malaysia. (2019). Malaysia Tourism Statistics in Brief. Retrieved 1st February, 2019, from http://www.tourism.gov.my/statistics

Tourism Planning Research Group (TPRG). (2015). Study on the Repositioning Pulau Perhentian as a Premier Ecotourism Destination. Putrajaya: Tourism Malaysia Retrieved from http://www.dmpm.nre.gov.my/images/webuser/docs/Laporan\%20Akhir\%20PERHENTIAN\% 20Ecotourism\%20plan\%20BM.pdf.

Vandarakis, D., Kyriakou, K., Sourianos, E., Hatiris, G., Kapsimalis, V., \& Sioulas, A. (2018). Carrying capacity assessment and environmentally-friendly based plans for tourism development in Rhodes Island, Greece.

Wilson, S. P., \& Verlis, K. M. (2017). The ugly face of tourism: Marine debris pollution linked to visitation in the southern Great Barrier Reef, Australia. Marine Pollution Bulletin, 117(1-2), 239-246.

World Tourism Organization (UNWTO). (2012). "World Tourism Organization UNWTO." Retrieved 1 st August 2012, 2012, from http://www2.unwto.org/.

World Tourism Organization (UNWTO). (2013). UNWTO Tourism Highlights 2013 Editions. In UNWTO (Series Ed.) (2013 ed.). Madrid, Spain: UNWTO. https://www.eunwto.org/doi/pdf/10.18111/9789284415427 
INTERNATIONAL JOURNAL OF ACADEMIC RESEARCH IN BUSINESS AND SOCIAL SCIENCES

Vol. 10, No. 8, 2020, E-ISSN: 2222-6990 @ 2020 HRMARS

Xiaojiang, Y. (2008). Growth and degradation in the Orient's 'Las Vegas': issues of environment in Macau. International Journal of Environmental Studies, 65(5), 667-683.

Yusof, Y., Awang, Z., Jusoff, K., \& Ibrahim, Y. (2017). The influence of green practices by non-green hotels on customer satisfaction and loyalty in hotel and tourism industry. International Journal of Green Economics, 11(1), 1-14.

Yusof, Y., Ibrahim, Y., \& Awang, Z. (2018). Awareness of Environmental Issues Among Consumers in the Malaysian Hotel Industry Driving Green Consumerism Through Strategic Sustainability Marketing (pp. 1-22): IGI Global.

Yusof, Z. B., \& Jamaludin, M. (2018). Green Operation Barriers of Malaysia Green Operators. Asian Journal of Quality of Life, 3(9), 77-86.

Zhang, L.-Y., \& Chung, S.-S. (2015). Assessing the social carrying capacity of diving sites in Mabul Island, Malaysia. Environmental Management, 56(6), 1467-1477.

Zhang, L.-Y., Chung, S.-S., \& Qiu, J.-W. (2016). Ecological carrying capacity assessment of diving site: A case study of Mabul Island, Malaysia. Journal of Environmental Management, 183, 253-259. 